\title{
Konsep Khalifatullah Terhadap Pengembangan Kepemimpinan Pendidikan Islam Persfektif M. Quraish Shihab dan Al-Gazali
}

\author{
Nikmatul Musayadah, Devy Habibi Muhammad, Ari Susandi \\ Sekolah Tinggi Agama Islam Muhammadiyah Probolinggo \\ * Corresponding Author. E-mail: nikmatulmusayadah232@gmail.com
}

\begin{abstract}
Abstrak
Tujuan Penelitian ini adalah untuk mengetahui Bagaimana Konsep khalifatullah dalam Perspektif M. Quraish Shihab dan Al-Ghazali, serta Persamaan dan Perbedaan Konsep Khalifah M. Quraish Shihab dan perspektif Al-Ghazali. Adapun jenis penelitian ini yaitu penelitiaan kepustakaan dan metode yang digunakan adalah metode deskriptif. Pemikiran M Quraish Shihab dan Al-Ghazali mengenai konsep khalifatullah memiliki pengertian yang sama, yaitu sebagai seorang pengganti, penerus atau pewaris. perbedaan pemikiran ke dua tokoh tersebut yaitu $M$ Quraish Shihab lebih cenderung pada peran manusia dalam mengemban tanggung jawab dan tugas yang ditentukan Tuhannya. Sedangkan Al-Ghazali lebih cenderung pada kesultanan atau mengenai hal yang berhubungan dengan politik dan pemerintahan.
\end{abstract}

Kata kunci: Khalifatullah, Kepemimpinan Pendidikan Islam, M. Quraish Shihab, Al-Ghazali

\begin{abstract}
The purpose of this study was to determine the concept of Khalifatullah in the perspective of M Quraish Shihab and Al-Ghazali, and the similarities and differences in the concept of Khalifatullah M Quraish Shihab and Al-Ghazali. As for this type of research, namely library research and the method used is descriptive method. M Quraish Shihab and Al-Ghazali thoughts on the concept of Khalifatullah have the same meaning, namely as a substitute, successor or heir. The difference between the two figures is that the $M$ Quraish Shihab are more inclined to the role of humans in carrying out the responsibilities and tasks that are determined by god, while the Al-Ghazali are more inclined to the sultanate or regarding matters related to politics and government.
\end{abstract}

Keywords: Khalifatullah,Islamic Education Leadership,M Quraish Shihab,Al-Ghazali

\section{Pendahuluan}

Kedudukan manusia dalam Al- Qur'an menjadikan dua fungsi pokok, yaitu sebagai seorang hamba ('abd), Pengabdi Allah dan khalifah allah yang dimaksud dengan dua fungsi, disini Alqur'an sangat menekankan terhadap manusia atas tugas-tugas yang harus dilaksanakan di dalam kehidupan di muka bumi ini dan bertanggung jawab atas kewajiban yang diembannya. (Raini, 2018)

Pertama, manusia adalah seorang hamba ('abd), manusia harus menjaga hubungannya dengan Tuhan yang telah menciptakan alam semesta. Maksud dari kata 'abd disini manusia sebagai hamba Allah harus melaksanakan kewajiban-kewajiban yang telah diperintahkan oleh allah sebagai bentuk pangabdian kepada Allah SWT yang telah memberikan segala sesuatu terhadap makhluknya; Kedua, manusia adalah khalifah, yang juga diperintahkan untuk menjaga hubungannya dengan sesama makhluk allah. Seseorang hamba dikatakan sukses sebagai hamba ('abd) apabila ia sukses menjalani tugas-tugasnya sebagai kholifah di muka bumi ini.(Khoirunnisa Fadliah, 2016)

Allah Swt menciptakan manusia sebagai khalifah di muka bumi ini, sebagai penghuni dibumi yang terhampar luas ini, hal ini merupakan ketentuan Allah yang telah menciptakan alam semesta ini. Allah Swt menciptakan seorang hamba ('abd) sebagai khalîfah di muka bumi ini tak lain tujuannya hanya untuk beribadah dan mengabdi kepadanya sebagai bentuk rasa syukur terhadap sesuatu yang telah diberikan 
olehnya, sebagai khalifah manusia mempunyai kewajiban amal ma'ruf nahi munkar di muka bumi, bersikap adil dalam memutuskan segala perkara yang terjadi, dan tidak bersikap sewenang-wenang kepada orang yang yang lebih rendah/ kepada rakyatnya.(Handayani, 2020)

Muthaharri dan Mohammad Daud Ali berpendapat bahwasanya Tuhan menciptakan manusia menjadikannya sebagai khalīfah di bumi. Sehubungan dengan perihal tersebut, H.M. Rasjidi (dalam Ali, 2010,hal.14) juga mengatakan bahwasanya dalam surat AlBaqarah ayat 30 terdapat kata "menjadi khalifah" arti dari kata tersebut tersirat makna bahwa Allah telah menjadikan manusia sebagai wakil atau pemimpin dimuka bumi ini sebagai pemegang kekuasaannya untuk mengurus dunia dengan jalan melakukan segala sesuatu yang diperintahnya dan menjauhi segala sesuatu yang dilarangnya. Husein (2008:280), makna kata khalifah berasal dari bahasa arab yaitu "khalf" yang artinya di belakang, yaitu sebagai pengganti yang di depan apabila yang didepan berhalangan, baik diluar shalat ataupun di dalam shalat. Dan sependapat juga dengan Muhaimin, dkk, (2008:22), mengatakan bahwa kata khaliffa herasal dari bahasa arab yaitu "khalf" (menggantikan, mengganti), atau kata khalaf (orang yang datang). (Lisnawati, Abdussalam, \& Wibisana, 2016)

Dalam surat Al-Baqarah ayat 30 dan 31 dijelaskan bahwa Nabī Adam setelah di angkat sebagai khalīfah dimuka bumi ia kemudian diberikan pengajaran dan pengetahuan. Dalam hal ini terdapat makna yang tersirat yakni Terdapat beberapa syarat yang bersifat teknis dan keterampilan yang harus dimiliki oleh seseorang yang ditugaskan sebagai khalīfah, seorang khalîfah perlu memiliki pengetahuan, ketrampilan, mental yang dewasa serta pendidikan pada umumnya, baik pendidikan formal ataupun non-formal (Lisnawati et al., 2016)

Khalifah juga mempunyai tanggung jawab terhadap tegaknya ajaran Islam dalam hal urusan dunia dan akkhiratnya umat islam, yakni dalam pendidikan keagamaanya dan dalam kesejahteraannya, seorang khalifah tidak hanya bertanggung jawab untuk memimpin dalam suatu kelompok kecil atau jamaah umat Islam saja. Dalam hal ini dapat kita lihat bahwasannya salah satu unsur pendidikan islam adalah begitu pentingnya peran seorang khalifah atau seorang pemimpin dalam pengembangan pendidikan Islam. Seorang pemimpin harus memiliki potensi untuk mensosialisasikan lembaga pendidikan Islam. (Raini, 2018)

Menurut pandangan Ibnu Khaldun pendidikan merupakan suatu usaha untuk menciptakan masyarakat yang berbudaya serta usaha untuk melestarikan eksistensi generasi selanjutnya, maka dari itu untuk mengembangkan sumber daya manusia yang berkualitas perlu adanya pendidikan agar terarah dengan baik dan benar. Dengan adanya pendidikan yang baik dan benar maka akan terjadi proses penumbuh kembangan eksistensi manusia yang bermasyarakat dan berbudaya yang baik dalam tata kehidupan yang berdimensi lokal, nasional, dan global ini. Adapun pendidikan tidak hanya sekedar proses transfer of knowledge, melainkan sebagai jalan, petunjuk sekaligus penangkal dalam berbagai fenomena sosial. (Khoirunnisa Fadliah, 2016)

Dalam membentuk watak pribadi yang baik sesuai dengan ajaran-ajaran agama islam, manusia perlu belajar pendidikan islam dengan mentransfer sejumlah ilmu baik ilmu umum ataupun agama. Dengan memiliki ilmu pengetahuan dan akhlak yang baik manusia bisa membentuk berbagai kebudayaankebudayaan yang bermanfaat untuk seluruh penduduk bumi. Maka dari itu manusia di jadikan khalifatullah sebagai Rahmatal Lil'alamin. Manusia tidak dapat menata sebuah kebudayaan secara ideal tanpa sebuah pendidikan. Seorang khalifah harus memiliki karakter yang harus dibangun dalam sebuah kepemimpinan pengembangan pendidikan islam diantaranya adalah seorang khalifah harus memiliki kecerdasan emosional, nyali, kematangan karakter, dan prinsip, karakter ini semua berasal dari cerminan kepemimpinan yang didasarkan pada kekhalifahan.(Raini, 2018)

Manusia diberikan kecerdasan akal oleh Allah namun tanpa disertai bimbingan iman atau pendidikan keagamaan maka akan membuatnya kehilangan arah. Manusia dijadikan khalifah oleh Allah untuk menjaga kehidupan dibumi untuk itu, manusia harus memiliki kecerdasan yang diimbangi dengan keimanan yang baik. Dalam memnunutut ilmu atau mempelajari ilmu pengetahuan kita boleh 
belajar dimana saja melalui para ulama' atau para guru yang sudah mahir.(Lisnawati et al., 2016)

Sesungguhnya setiap manusia yang ada dibumi ini memiliki kemampuan menjadi seorang pemimpin agar supaya manusia mampu memanfaatkan, mengembangkan dan memperdayakan sumber daya manusia dan juga sumber daya alam yang ada dibumi ini. Namun pada masa ini manusia yang dijadikan sebagai khalifah tidak sesuai dengan keteladanan dan ajaran-ajaran nabi dalam membangan sebuah kelembagaan yakni kurang memiliki jiwa kepemimpinannya dalam memimpin suatu lembaga, kurang berpatriotisme, kurang memiliki sebuah keberanian dalam memperjuangkan kebenaran, dan tidak melakukan perubahan dengan menghadapi sebuah resiko dalam mencapai tujuan lembaga tersebut. (Saebani, 2021)

Al-Qur'an menjelaskan manusia dijadikan khalifah dalam pengertian kuasa. Karena kedudukan itulah manusia memiliki berbagai hak, kewajiban serta tanggung jawab, yang semua itu adalah amanah yang harus dipertanggung jawabkan oleh manusia terhadap Tuhannya. Al-Qur'an banyak menjelaskan tentang Khalifah agar dijadikan cerminan oleh manusia bagaimana ia akan menjadi pemimpin yang cerdas, berperasaan, amanah , serta memiliki tanggung jawab yang besar dalam menegakkan ajaran-ajaran islam dan menjadikan sumber daya manusia dan kemampuannya sebagai sebuah kekuatan dalam memimpin.(Rachman, 2016)

Khalifah disebut wakil Tuhan yang tak lain adalah manusia yang mana manusia dibatasi dengan aturan-aturan serta ketentanketentuan yang telah di tetapkan oleh Tuhannya, yakni manusia harus mengikuti hukum-hukum Tuhan yang telah tertulis dalam kitab suci Al-Qur'an atau yang tersirat dalam kandungannya. Seorang khalifah yang melanggar batas aturan-aturan Tuhan adalah seorang khalifah yang mengingkari status dan perannya serta menghianati kepercayaan yang diberikan oleh Tuhannya, maka ia akan dimintai pertanggung jawaban oleh Tuhannya atas apa yang telah dilakukannya. (Lisnawati et al., 2016)

Seorang pemimimpin sangat diperlukan, terutama dalam suatu Negara agar supaya ketertiban sosial dan ajaran-ajaran agama dapat diwujudkan serta kebutuhankebutuhan yang perlukan masyarakat dapat berjalan dengan baik dan benar. Al-Ghazali mengungkapkan bahwasannya salah satu kewajiban syari'at adalah dengan memilih atau mengangkat seorang pemimpin untuk memimpin sebuah Negara, maka berdosalah bagi wakil dari masyarakat apabila tidak mau memilih atau mengangkat seorang pemimpin dan bagi bangsa yang tak mau mengangkat seorang pemimpin. Bahkan wakil dari masyarakat boleh memilih pemimpin yang zalim karena itu lebih baik dari pada tidak adanya seorang pemimpin, Karena akan menyebabkan kekacauan apabila suatu Negara atau bangsa tanpa adanya seorang pemimpin.(Hakim, 2018)

Dari uraian latar belakang diatas maka rumusan masalah dapat dirumuskan antara lain, 1) Bagaimana Konsep khalifatullah dalam Perspektif M. Quraish Shihab? 2) Bagaimana Konsep khalifah menurut perspektif AlGhazali? 3) Bagaimana Persamaan dan Perbedaan Konsep Khalifah M. Quraish Shihab dan perspektif Al-Ghazali?

Penelitian ini secara umum diarahkan pada upaya menjawab rumusan masalah yaitu 1) untuk mengetahui Konsep khalifatullah dalam Perspektif M. Quraish Shihab. 2) Untuk mengetahui Konsep khalifah menurut perspektif Al-Ghazali. 3) Persamaan dan Perbedaan Konsep Khalifah M. Quraish Shihab dan perspektif Al-Ghazali

\section{Pembahasan \\ Kholifah}

Secara bahasa kata "khalifah" diambil dari kata kerja "khalafa"

yang berarti ganti atau "khalafa lahu/khalafa alaihi" yang berarti mengganti atau "khalafahu" yang berarti menggantikan.(Ida, 2017)

Kata khalifah memiliki 2 makna: Pertama, menjelaskan bahwasannya hakikat khalifah bersifat umum yakni kepemimpinan bagi seluruh umat islam didunia, Kedua, menyebutkan tentang kewajiban-kewajiban khalifah, yaitu: (1) mempunyai kewajiban melaksanakan ajaran-ajaran syari'at keislaman, (2) mempunyai kewajiban untuk menjalankan dakwah baik didalam ataupun diluar Negara yang ditempati pada seluruh umat islam dengan cara jihad fii sabiilillah. (Agung Subekti \& Nurcholiq, 2019) 
Jurnal Edumaspul, 5 (2), Year 2021- 492

Nikmatul Musayadah, Devy Habibi Muhammad, Ari Susandi

\begin{abstract}
Quraish Shihab menjelaskan bahwasannya konsep khalifah harus mendasarkan segala sesuatu pada Alqur'an dan As-Sunnah. Selain itu Juga melaksanakan pendidikan menurut aturan islam yang juga berpegangan pada Al-Qur'an dan As-Sunnah. Hal itu untuk menjadikan manusia memiliki pribadi muslim yang seutuhnya. (Azizah \& Raini, 2018)
\end{abstract}

Seorang Khalifatullah menurut $M$. Quraish Shihab diharuskan memiliki beberapa karakter. Manusia sebagai Khalifah secara individu ataupun kelompok, harus memiliki kemampuan dalam menjalankan kewajibannya sebagai hamba Tuhannya, untuk menjadikan dunia sesuai dengan aturan yang telah ditetapkan oleh Tuhannya.(Rachman, 2016)

Berdasarkan analisisnya, M. Quraish Shihab mengambil kesimpulan,yaitu:

1. Kata khalifah yang telah disebutkan dalam Al-Qur'an mengenai tentang siapa yang telah diamanahi kekuasaan dalam mengelola wilayah, baik wilayah terbatas ataupun wilayah yang luas.

2. Manusia sebagai khalifah harus memiliki potensi, bahkan manusia sering mengikuti hawa nafsunya sehingga dapat melakukan kesalahan dan kekeliruan.

Kepemimpinan menurut Griffin dan

Ebert adalah sebuah proses untuk memberikan motivasi kepada orang lain agar mau bekerja untuk mencapai sebuah ketetapan tujuaannya. Kepemimpinan juga bisa diartikan sebagai kemampuan yang dimiliki oleh seseorang dalam meyakinkan dan mengarahkan seseorang yang kurang memiliki pengetahuan dan melakukan kerjasama untuk mencapai sebuah tujuan secara suka rela. Dikatakan oleh Rahman bahwasannya kepemimpinan dalam islam adalah mengungkapkan tentang kepribadiaan Rosulullah SAW. (Muzammil, 2018)

Kepemimpinan merupakan sebuah kemampuan seorang pemimpin dalam lapangan pendidikan untuk mengarahkan,mengkoordinasikan, serta menumbuhkan semangat untuk bekerja terhadap staf-staf atau bawahannya untuk kepentingan bersama. Selain itu sebagai Seorang pemimpin juga harus memiliki kemampuan kerja sama yang baik guna memberikan semangat atau motivasi terhadap orang-orang yang frustasi dalam pengambilan keputusan dan tindakan yang akan menyebabkan ketidaksesuaian dalam menjalankan tugasnya.(Takwil, 2020)

Menurut imam Ghazali menyatakan bahwasannya sebuah kekuasaan memiliki subtansi yang terletak pada kepopuleran atau ketenaran. Dan hal ini akan menjadi tercela bilamana seorang pemimpin tidak dapat menjalankan amanah dan mengendalikan kekuasaannya untuk kepentingan rakyatnya. Dan dapat menjadi sebuah pujian bilamana melaksanakan amanahnya berdasarkan ajaran-ajaran yang telah ditetapkan Tuhannya. (Takwil, 2020)

\section{Metode Penelitian}

Adapun jenis penelitian ini yaitu penelitiaan kepustakaan yakni data yang berupa teori yang diambil dari berbagai jurnal dan skipsi. Adapun cara pengumpulan data yaitu dengan mengambil dari beberapa skripsi dan beberapa jurnal dengan membaca, memahami dan menela'ah sebuah permasalahan yang terkait dengan permasalahan yang diteliti.(Harimulyo, Prasetiya, \& Muhammad, 2021) Sedangkan pendekatan dalam penelitiaan ini menggunakan pendekatan kualitatif dan analisis data yang digunakan adalah Al-Qur'an dan Hadits.(Ida, 2017)

\section{Analisis Data}

Metode yang digunakan dalam penelitian ini adalah metode study literatur (library research) yakni penelitian kepustakaan. (Prasetiya, 2021)Adapun dalam memperoleh data, informasi, serta fakta untuk melengkapi dan menjabarkan permasalahan dalam penelitian ini, maka dalam penelitian ini metode yang digunakan adalah metode deskriptif.(Benny Prasetya, Syams, M. Faisyal, 2020) Adapun tujuan dari penelitian deskriptif adalah menjabarkan secara sistematik, akurat fakta serta karakteristik mengenai populasi dan bidang tertentu.(Ida, 2017)

\section{Teknik Analisis Data}

Adapun penelitian ini adalah penelitian book survey atau biasa disebut penelitian kepustakaan.(Ari Susandi, Irmawati Apriliana, Ningsih, 2020) Maka dari itu, dalam pengumpulan data teknik yang diambil adalah pengumpulan data literer. Penulis mengumpulkan data dengan cara mencari buku-buku kepustakaan yang relevan yang 
berkaitan dengan permasalahan yang akan diteliti. Selain itu penulis juga memilah-milih pokok pembahasan yang akan dimasukkan dalam penulisanserta menyusunnya secara sistematis.(Ida, 2017)

\section{Hasil Penelitian \\ Konsep Khalifah Menurut perspektif $M$. Quraish Shihab}

Menurut bahasa kata "khalïfa $\hbar "$ pada umumnya adalah yang menggantikan atau bisa dikatakan yang datang sesudah siapa yang datang sebelumnya. Untuk kata tersebut yang digunakan dalam Al-Qur'an adalah dua bentuk jamak,yakni kata "khala'if" dan " khulafa"” yang mana kata tersebut diambil dari kata "khalf" yang artinya adalah belakang. Selain itu kata "khalf" juga sering diartikan para pengganti. Para pengganti generasi selanjutnya, agar dapat meneruskan hukum-hukum serta ajaran-ajaran yang ditetapkan oleh Tuhannya.(Lisnawati et al., 2016)

Selanjutnya, Quraish

Shihab menjelaskan penafsiran ayat yang sama yaitu tentang kaum 'Ad yang mana kaum 'ad adalah kaum yang dijadikan khalifah oleh Allah sesudah kaum Nabi Nuh diturunkan adzab. Maka dari itu kekhalifahan disini mempunyai tujuan menggantikan kaum Nabi Nuh untuk memakmurkan bumi, karna hal inilah kaum 'ad adalah kaum yang pertama kali membangun peradaban manusia sesudah terjadinya angin topan Nabi Nuh as. (Lisnawati et al., 2016)

Dari berbagai pengertian diatas, sudah sangat jelas bahwasannya pengertian dari pada khalifah adalah mengenai peran manusia sebagai khalifah Allah atau orang yang mewakili Tuhannya dimuka bumi ini. Jadi Allah sendiri sudah sangat mempercayai manusia untuk mengelola, mengatur, merencanakan serta mengawasi seluruh kehidupan dimuka bumi ini. Untuk itu jadi konsep khalifatullah disini merupakan sebuah konsep leadership yang mempunyai makna sangat luas yaitu mengenai tentang manusia sebagai wakil Allah yang mempunyai tugas sebagai pengelola dan pemimpin bagi seluruh kehidupan dimuka bumi ini. Termasuk pula dalam kehidupan umat manusia didalam sebuah komunitas.(Rachman, 2016)

M Quraish Shihab menjelaskan bahwasannya konsep khalifah harus disesuaikan dengan : (1) Yahdunaa bi
Amrinaa, dapat menghantar umat islam pada tujuan yang sesuai dengan jalan kami (Allah). Manusia sebagai seorang khalifah tidak memiliki sifat ego yang hanya mementingkan kepentingan sendiri, bangsa ataupun kelompok akan tetapi seorang khalifah harus bersikap dan berpikirsesuai dengan ketetapan dan kehendak Allah SWT. Selain itu manusia sebagai khalifah juga mempunyai kewajiban untu beribadah kepada Allah SWT dan selalu berbuat kebaikan didalam hidupnya. (2) Aabidin (mendirikan sholat dan menunaikan zakat), dengan mengerjakan sholat itu artinya manusia menjaga hubungan yang baik dengan Tuhannya, sedangkan menunaikan zakat itu artinya manusia menjaga keharmonisan atau hubungan manusia dengan manusia lainnya, karena manusia dijadikan khalifah oleh Allah untuk menjadi pengelola dalam suatu wilayah, untuk itu maka mempunyai kewajiban untuk membangun suatu kehidupan yang hubungannya baik dengan Allah, hubungan dengan masyarakat harmonis atau rukun, agama, budaya serta akalnya terpelihara. (3) Yuqinun (keyakinan yang kuat). Manusia sebagai seorang khalifah harus meyakini bahwasannya ia bisa memelihara, mengayomi, serta membimbing supaya setiap manusia mencapai tujuan yang diharapkan penciptanya. Manusia dijadikan sebagai khalifah harus memiliki keyakinan dalam menegakkan keadilan dan kebenaran serta mencegah pada kebathilan. Karena manusia sebagai khalifatullah mempunyai funfsi yang begitu besar didalam membangun sendi-sendi kehidupan dimuka bumi ini. (4) Shabaru (tabah dan sabar), manusia sebagai khalifah Allah harus sabar dan tabah didalam mengerjakan amanah dan tanggung jawabnya untuk memakmurkan kehidupan dibumi dengan melakukan segala sesuatu yang sesuai dengan hukum-hukum Tuhannya.(5) Melaksanakan dan mendasarkan sebuah pendidikan yang pengambilannya bersumber pada Al-Qur'an dan Assunnah untuk menciptakan muslim yang mempunyai kepribadian yang baik. Karena sesungguhnya tujuan dari sebuah pendidikan ialah untuk menciptakan manusia yang sempurna dengan memiliki ketakwaan. (Azizah \& Raini, 2018)

Allah menjadikan manusia sebagai Khalifah tak lain untuk memakmurkan kehidupan dibumi. Penjelasan ini sering kali kita temui dalam ilmu-ilmu tafsir dalam ayat 
Jurnal Edumaspul, 5 (2), Year 2021- 494

Nikmatul Musayadah, Devy Habibi Muhammad, Ari Susandi

yang dibahas oleh peneliti. M Quraish Shihab menafsirkan surat Al-A'raf ayat 69 yang artinya berbunyi " menjadikan kamu khalifahkhalifah" yakni para pengganti yang mempuanyai kuasa dan yang memiliki tanggung jawab untuk memakmurkan bumi. (Lisnawati et al., 2016)

Manusia mengemban tugas sebagai khalifah dibumi, untuk itu Allah menjadikan status manusia berbeda antara yang satu dengan yang lainnya. Karena hal ini berhubungan dengan fungsinya manusia sebagai khalifah. Hamka (1983:164) menafsirkan dalam surat Al-An'am ayat 165, menjelaskan bahwasannya kewajiban sebagai khalifah ialah memakmurkan bumi, menggunakan akal untuk berusaha, mencari, mecipta atau menambah keilmuan dan membangun sebuah kebudayaan dan kemajuan. Selain itu juga mengatur siasat bangsa, Negara dan benua. Untuk itu dalam melaksanakan kewajibannya sebagai khalifah, status manusia tidaklah sama, sebab manusia diberikan kelebihan dari yang lain. (Lisnawati et al., 2016)

Kewajiban manusia sebagai seorang Khalifah yaitu untuk menjaga dan memelihara amanah yang ditetapkan oleh Allah kepadanya, setelah bumi, gunung, dan langit enggan untuk memeliharanya. Amanah yang dimaksud disini adalah berupa kewajiban untuk memakmurkan bumi dengan menjalankan ketetapan hukum darinya, dalam menjalan kehidupan dibumi ini. M Qurais Shihab menjelaskan bahwasannya manusia sebagai khalifah ialah mengenai siapa yang akan diberi kekuasaan untuk mengelola suatu wilayah yang kecil atupun wilayah yang besar. Dari gabungan penjelasan diatas, manusia dijadikan khalifah untuk mengelola wilayah baik besar atau kecil, ia mempunyai kewajiban untuk membangun masyarakat yang mempunyai hubungan baik dengan Allah, kehidupan masyarakat yang rukun dan harmonis, budaya, akal serta agamanya juga terpelihara. Dengan mengerjakan sholat itu artinya manusia menjaga hubungan yang baik dengan Tuhannya, , sedangkan menunaikan zakat itu artinya manusia menjaga keharmonisan atau hubungan manusia dengan manusia lainnya.(Khoirunnisa Fadliah, 2016)

\section{Konsep Khalifah Menurut Perspektif Imam Ghozali}

Menurut syari'ah , kata " Khilafah" hanya dipergunakan untuk sebutan seseorang yang menjadi pengganti Rosuluulah SAW dalam kepemimpinan Negara keislaman. Pengertian ini ada pada masa awal islam. Setelah itu, pada perkembangan berikutnya kata "Khilafah" di pergunakan dalam penyebutan sebuah Negara Islam itu sendiri. (Agung Subekti \& Nurcholiq, 2019)

Dalam Al-Qur'an dapat ditelusuri asal muasal konsep kepemimpinan yang mana dalam kitab suci ini dapat ditelusuri lebih mendalam mengenai kata khalifah, dalam AlQur'an kata khalifah telah disebutkan 127 kali dalam 12 kali kejadian. Dalam bahasa, kata Khalifah memiliki beberapa makna apabila dilihat dari kata asalnya yaitu "khalafa" yang memiliki arti meninggalkanatau pengganti. Berarti kata khalifah adalah isim fa'il yang brarti pelaku, atau bisa dikatakan pewaris atau penerus.(Hakim, 2018)

Istilah kepemimpinan dalam islam sering disebut dengan kata "imamah", bahkan kata yang memiliki makna kepemimpinan atau kata yang berkaitan dengan kepemimpinan didalam islam terdapat tujuh macam, yakni khalifah, sultan, rais, wali, malik, 'amir dan ulil amrisebagai fokus penulisan kata khalifah berasal dari kata khalafa yang awalnya mempunyai makna "dibelakang". Ada dua istilah yang digunakan Al-Qur'an dalam menggambarkan cirri seorang pemimpin, ketika keberadaannya ada dibelakang maka akan menjadi pendorong, dan apabila keberadaanya didepan maka akan menjadi panutan, serta mengikuti arah atau jalan yang dituju seorang pemimpin. Disisi lain, ada dua macam makna kata khalifah pertama, kata khalifah digunakan untuk kepala Negara atau seseorang yang mempunyai jabatan sultan. Kedua, Allah menciptakan manusia dengan sempurna dimuka bumi ini sesuai dengan fungsi manusia itu sendiri. (Agung Subekti \& Nurcholiq, 2019)

Selain konsep Khalifah kepemimpinan juga bisa diartikan sebagai konsep Imamah. Kata Imamah sangat identik dengan kata khalifah. Perbedaaanya adalah kata Khalifah dipakai dalam kalangan suni, sedangkan kata Imamah sering digunakan dalam kalangan Syi'ah. Akan tetapi hal ini tidak terlalu dipermasalahkan oleh Al-Ghazali baik sebutan 
imam ataupun khalifah yang terpenting adalah subtansi dari kepemimpinan tersebut. Bahkan Al-Ghazali lebih condong untuk memakai sebutan Imam dari pada memakai sebutan Khalifah padahal beliau adalah tokoh ulama' yang masyhur dikalangan suni. Hal ini dapat dilihat dari beberapa tulisannya yang banyak membahas tentang kepemimpinan beserta aspek-aspeknya. (Hakim, 2018)

Dalam pandangan beberapa ulama' kedudukan seorang khalifah memiliki pandangan yang berbeda-beda diantaranya ialah : sebagian ulama' memandang bahwasannya seorang khilafah sebagai penampakan agama yaitu seseorang yang hanya menjalankan urusan keagamaan maksudnya tidak menjalankan system pemerintahan atau bidang kekuasaan, seperti perdagangan, hukum keluarga, serta ibadahibadah mahdhah. Sedangkan sebagian ulama' lainnya memandang bahwasannya seoarang khilafah sebagai penampakan politik atau pemerintahan yaitu seseorang yang menjalankan bidang kekuasaan atau yang berkaitan dengan politik dan system pemerintahan. (Agung Subekti \& Nurcholiq, 2019)

Dari penjelasan diatas, maka seorang pemimpin memiliki tugas bagaimana cara ia memengaruhi rakyatnya agar bisa menjalankan tujuan yang akan dicapai. Dikatakan oleh Dirawat bahwasannya kepemimpinan didalam sebuah pendidikan adalah kemampuan yang dimiliki oleh seseorang untuk mengkoordinir dan mempengaruhi beserta menggerakkan hati seseorang yang berhubungan dengan ilmu pendidikan, pengajaran serta pelaksanaan pendidikan agar aktivitas-aktivitas yang dilakukan dapat menjadi lebih baik dan tepat sasaran untuk mencapai sebuah tujuan pembelajaran. Hal terpenting didalam mencapai sebuah seni tujuan pendidikan menurut Al-Ghazali adalah bahwasannya segala sesuatu apapun pasti akan butuh pada seorang pemimpin atau kepemimpinan. (Takwil, 2020)

Al-Ghazali mengatakan bahwasannya hakikat kepemimpinan adalah pengaruh. Sedangkan pemimpin itu sendiri adalah orang yang memiliki pengaruh atau orang yang sangat berpengaruh dalam masyarakat. Apabila tidak memiliki pengaruh maka tidak mungkin disebut seorang pemimpin dalam artian kedudukan seorang pemimpin sangat berpengaruh bagi manusia. Timbulnya pengaruh tersebut tak lain karena pemimpin mempunyai nilai-nilai yang mulia, seperti memiliki akhlaq yang mulia, pemimpin yang pemahaman agamanya luas, serta pemimpin yang memiliki intelektualitas yang baik. Seorang pemimpin akan mampu mempertahankan kedudukannya sebagai pemimpin apabila memiliki 3 poin tersebut, dan akan menjadi corak yang has didalam pemikiran Al-Ghazali. (Afriansyah, 2017)

Al-Ghazali memberi peringatan bahwasannya seorang pemimpin atau Khalifah tidak diperbolehkan untuk meninggalkan seorang ulama'. Akan tetapi seorang pemimpin atau khalifah harus pintar dalam memilih ulama' untuk dijadikan penasehat. Karena seorang Ulama' ada kalanya ulama' sejati dan ulama' yang jahat. Ulama' yang sejati beliau tidak pernah berharap suatu balasan uang dari seorang pemimpin atau khalifah, beliau menasehati dengan ikhlas karena ia benar-benar ingin memperbaiki diri seorang pemimpin, memperbaiki bangsa, Negara serta masyarakat. Sedangkan Ulama' yang jahat akan menyebabkan kerusakan pada Negara. Ia selalu memuji seorang pemimpin dengan tidak wajar, tidak benar-benar menasehati melainkan tujuannya adalah hanya mengarah pada duniawi saja(Hasib, 2017).

\section{Persamaan dan Perbedaan Konsep Khalifah M. Quraish Shihab dan perspektif Al-Ghazali.}

Hasil dari pemikiran M Quraish Shihab dan Imam Ghazali mengenai konsep khalifatullah memiliki pengertian yang sama, yaitu seorang pengganti, penerus atau pewaris. Karena kedudukan itulah manusia memiliki berbagai hak, kewajiban serta tanggung jawab, yang semua itu adalah amanah yang harus dipertanggung jawabkan oleh manusia terhadap Tuhannya. (Rachman, 2016). Seorang Khalifah tidak hanya bertanggung jawab menjadi seorang pemimpin dalam sebuah kelompok atau jam'iyah saja tetapi juga bertanggung atas tegaknya hukum keislaman dalam urusan dunia dan akhiratnya.(Raini, 2018)

M Quraish Shihab menafsirkan surat Al-A'raf ayat 69 yang artinya berbunyi “ menjadikan kamu khalifah-khalifah" yakni para pengganti yang mempuanyai kuasa dan 
yang memiliki tanggung jawab untuk memakmurkan bumi. (Lisnawati et al., 2016) Ada dua macam makna kata khalifah pertama, kata khalifah digunakan untuk kepala Negara atau seseorang yang mempunyai jabatan sultan. Kedua, Allah menciptakan manusia dengan sempurna dimuka bumi ini sesuai dengan fungsi manusia itu sendiri. (Agung Subekti \& Nurcholiq, 2019). Kata Khalifah dipakai dalam kalangan suni, sedangkan kata Imamah sering digunakan dalam kalangan Syi'ah. (Hakim, 2018)

$$
\text { Al-Ghazali tidak terlalu }
$$

mempermasalahkan sebutan imam ataupun khalifah bahkan Al-Ghazali lebih condong untuk memakai sebutan Imam dari pada memakai sebutan Khalifah padahal beliau adalah tokoh ulama' yang masyhur dikalangan suni. (Hakim, 2018). Adapun perbedaan pemikiran ke dua tokoh tersebut yaitu M Quraish Shihab dalam konsep khalifatullah lebih cenderung pada peran manusia dalam mengemban tanggung jawab dan tugas yang ditentukan Tuhannya. Sedangkan konsep khalifah Imam Ghazali lebih cenderung pada konsep kesultanan atau mengenai hal yang berhubungan dengan politik dan pemerintahan.

\section{Kesimpulan}

1. M Quraish Shihab menjelaskan bahwasannya konsep khalifah harus disesuaikan dengan : Yahdunaa bi Amrinaa, dapat menghantar umat islam pada tujuan yang sesuai dengan jalan kami (Allah), Aabidin (mendirikan sholat dan menunaikan zakat), Yuqinun (keyakinan yang kuat), Shabaru (tabah dan sabar), Melaksanakan dan mendasarkan sebuah pendidikan yang pengambilannya bersumber pada AlQur'an dan Assunnah.

2. Al-Ghazali mengatakan bahwasannya hakikat kepemimpinan atau Khalifah adalah pengaruh. Sedangkan pemimpin itu sendiri adalah orang yang memiliki pengaruh atau orang yang sangat berpengaruh dalam masyarakat. Hal terpenting didalam mencapai sebuah seni tujuan pendidikan menurut Al-Ghazali adalah bahwasannya segala sesuatu apapun pasti akan butuh pada seorang pemimpin atau kepemimpinan.
3. Adapun persamaan pemikiran M Quraish Shihab dan Imam Ghazali mengenai konsep khalifatullah ialah sama-sama mengartikan khalifah sebagai seorang pengganti, penerus atau pewaris. Sedangkan perbedaan pemikiran ke dua tokoh tersebut yaitu M Quraish Shihab lebih cenderung pada peran manusia dalam mengemban tanggung jawab dan tugas yang ditentukan Tuhannya. Sedangkan Imam Ghazali lebih cenderung pada konsep kesultanan atau mengenai hal yang berhubungan dengan politik dan pemerintahan.

\section{Daftar Pustaka}

Afriansyah, A. (2017). KONSEP PEMIMPIN IDEAL MENURUT AL-GHAZ Ā L I. 1(2), 8294.

Agung Subekti, M. Y., \& Nurcholiq, M. (2019). KEPEMIMPINAN PENDIDIKAN ISLAM (Analisis Makna Kata "Khalifah" dalam Al Qur'an). Journal PIWULANG, 2(1), 62. https://doi.org/10.32478/piwulang.v2i1. 302

Ari Susandi, Irmawati Apriliana, Ningsih, R. H. L. (2020). Peran Orang Tua dalam Meningkatkan Motivasi Belajar Siswa di Sekolah Dasar. Jurnal Kependidikan Dasar Islam Berbasis Sains, 6(1), 84-91. Retrieved from http://journal.ubpkarawang.ac.id/mahas iswa/index.php/IJPSE/article/view/58

Azizah, M., \& Raini, R. (2018). Konsep Khalifatullah Dan Implikasimya Terhadap Pendidikan Islam Perspektif M. Quraish Shihab. CENDEKIA: Jurnal Studi Keislaman, $4(2)$. https://doi.org/10.37348/cendekia.v4i2. 59

Benny Prasetya, Syams, M. Faisyal, M. U. (2020). Makna Religiusitas bagi Kaum Waria. 20(1), 95-108.

Hakim, M. (2018). Konsep Kepemimpinan Menurut Al- Ghazālī Masykur Hakim.

Handayani, W. (2020). Konsep Khalifah dan Implikasinya terhadap Tujuan Pendidikan. Human Relations, 3(1), 1-8. Retrieved from http://search.ebscohost.com/login.aspx? direct=true \&AuthType $=i p$,shib \&db=bth\& $\mathrm{AN}=92948285 \&$ site $=$ edslive $\&$ scope $=$ site $\% 0 A h t t p: / / b i m p a c t a s s e s$ sment.net/sites/all/themes/bcorp_impac 
Jurnal Edumaspul, 5 (2), Year 2021- 497

Nikmatul Musayadah, Devy Habibi Muhammad, Ari Susandi,

t/pdfs/em_stakeholder_engagement.pdf \%0Ahttps://www.glo-

bus.com/help/helpFiles/CDJ-Pa

Harimulyo, M. S., Prasetiya, B., \& Muhammad, D. H. (2021). Nilai-Nilai Pendidikan Akhlak Dalam Kitab Risalatul Mu'awanah Dan Relevansinya. Jurnal Penelitian IPTEKS, 6(1), 72-89. https://doi.org/10.32528/ipteks.v6i1.52 53

Hasib, K. (2017). KONSEP SIYASAH DAN ADAB BERNEGARA MENURUT IMAM ALGHAZALI. 1-17.

Ida, N. F. (2017). Konsep Khalifatullah dalam al-Qur'an menurut M. Quraish Shihab dalam Tafsir al-Mishbah dan relevansinya dengan pendidik dalam pendidikan islam.

Khoirunnisa Fadliah. (2016). KONSEP KHALIFAH MENURUT M. QURAISH SHIHAB DAN IMPLIKASINYA TERHADAP PENDIDIKAN ISLAM. Konsep Khalifah Menurut M.Quraish Shihab Dan Implikasinya Terhadap Pendidikan Islam.

Lisnawati, Y., Abdussalam, A., \& Wibisana, W. (2016). Konsep Khalīfah Dalam AlQur'Ān Dan Implikasinya Terhadap Tujuan Pendidikan Islam (Studi Maudu'I Terhadap Konsep Khalīfah Dalam Tafsir Al-Misbah). TARBAWY: Indonesian Journal of Islamic Education, 2(1), 47. https://doi.org/10.17509/t.v2i1.3377

Muzammil, M. (2018). Konseptualisasi Kepemimpinan Islami dalam Pengembangan Pendidikan Islam. ATTURAS: Jurnal Studi Keislaman, 4(2), 256278. https://doi.org/10.33650/atturas.v4i2.335

Prasetiya, A. Y. B. (2021). ANALISIS INTERAKSI ADAB SEORANG MURID TERHADAP GURU DALAM PERSPEKTIF IMAM AL-GHAZALI Anwar. 30-40.

Rachman, F. (2016). Konsep Kholifatullah Sebagai Model Ideal Kepemimpinan Organisasi Sosial. Angewandte Chemie International Edition, 6(11), 951-952., $4(1), 1-28$.

Raini, M. A. dan. (2018). Konsep Khalifatullah dan Implikasinya terhadap Pendidikan Islam Perspektif M. Quraish Shihab. 4(d).

Saebani, M. (2021). Perspektif Al-Ghazali dalam Pengembangan Kepemimpinan Profetik pada Lembaga Pendidikan. Jurnal Kependidikan, 7(2), 395-407.

Takwil, M. (2020). KEPEMIMPINAN
PENDIDIKAN ISLAM DALAM PEMIKIRAN AL-GHAZALI. Jurnal Literasiologi, 3(3). https://doi.org/10.47783/literasiologi.v 3i3.108

\section{PROFIL PENULIS}

Nama saya Nikmatul Musayadah saya dilahirkan di probolinggonpada 03 maret 1997, sekarang saya kuliah pendidikan islam di Sekolah Tinggi Agama Islam Muhammadiyah Probolinggo untuk mendapatkan gelar Slalamat email nikmatulmusayadah232@gmail.com 